\section{Kastamonu Eğitim Dergisi Kastamonu Education Journal}

Temmuz 2019 Cilt:27 Sayı:4

kefdergi.kastamonu.edu.tr
Başvuru Tarihi/Received: 30.05 .2018

Kabul Tarihi/Accepted: 10.10 .2018

DOI: $10.24106 /$ kefdergi.3119

\title{
Ortaokul Öğrencilerinin Dinleme/İzleme Öz-Yeterliklerinin Çeşitli Değişkenlere Göre İncelenmesi'
}

\section{Evaluation of The Secondary School Student's Listening/Watching Self- Efficiency According to Various Factors}

\section{Öz}

\author{
Uğur DEMIRCAN², i. Seçkin AYDIN³
}

Problem Durumu: Bu çalışmada ortaokul öğrencilerinin dinleme/izleme becerisine yönelik öz yeterlik algıları sınıf düzeyi, cinsiyet, anne-baba eğitim durumu, önceki yıla ait Türkçe dersi başarı puanı gibi değişkenlere göre incelenmiştir.

Yöntem: Araştırma, “ilişkisel Tarama Modeli”nde betimsel bir çalışmadır. Bu model bağlamında araştırma, nicel araştırmaya bağlı olarak korelasyonel araştırma yönteminde gerçekleştirilmiştir. Öğrencilerin dinleme/izleme öz yeterlik düzeylerini belirlemek için geçerliği ve güvenirliği kanıtlanmış "Dinleme Öz Yeterlik Ölçeği” kullanılmıştır. Ölçek kullanılmadan önce doğrulayıcı faktör analizi yapılarak ölçeğin geçerlik ve güvenirliğine ek kanıt elde edilmiştir. Araştırma İzmir ilinde 6,7 ve 8. sınıflarda öğrenim gören 748 ortaokul öğrencisi üzerinde yapılmıştır.

Bulgular: Araştrrma sonucunda cinsiyete göre dinleme öz yeterliğinin kız öğrencilerin lehine anlamlı şekilde farklılaştı̆̆ı; sınıf düzeyine göre 6. sınıfların en yüksek, 8. sınıfların en düşük dinleme öz yeterliğine sahip olduğu; anne-baba öğrenim durumuna göre veli eğitim durumu yüksek olan öğrencilerin dinleme öz yeterliklerinin de yüksek olduğu; önceki yıl Türkçe dersi başarı puanları ile dinleme öz yeterliği arasında olumlu yönde bir ilişkinin olduğu sonuçlarına ulaşıımıştır.

Sonuç ve Öneriler: Elde edilen sonuçlar alandaki diğer çalışmalarla karşılaştırılmış ve yorumlanmıştır, sonuçlardan hareketle alana öneriler getirilmiştir.

\section{Anahtar Kelimeler: Dinleme, İzleme, Öz-Yeterlik}

\section{Abstract}

Problem Status: In this study, the self-efficiency perceptions of listening / watching skills of middle school students were examined according to the variables such as class level, gender, parental education status, and achievement score of Turkish lesson of the previous year.

Method: The research is a descriptive study on "Relational Screening Model". In the context of this model, the research was carried out in a correlational research method depending on the quantitative research. The "Listening Self- Efficiency Scale", which is valid and reliable, has been used to determine listening / watching self- efficiency levels of students. Confirmatory factor analysis was performed before the scale was used to obtain additional evidence of validity and reliability of the scale. The research was carried out on 748 middle school students in 6 th, 7 th and 8th grade in İzmir.

Findings: As a result of the research, listening according to sex was achieved as a result of the difference in meaningfulness in favor of female students. According to the class level the sixth grade has the highest listening self- efficiency, 8th grade has the lowest listening self- efficiency. According to parents' educational status it was concluded that the listening self-efficacy of the students with high learning status of their parents was also high. It was concluded that there was a positive relationship between the achievement scores of the previous year Turkish lesson and listening self- efficiency.

Results and Suggestions: The results obtained are compared with the other studies in the area and interpreted. Some suggestions were made to the field with the considering results.

Keywords: Listening, Watching, Self- Efficiency

1. Bu çalışma birinci yazarın yüksek lisans tezinden üretilmiştir.

2. Milli Eğitim Müdürlügüu, İzmir Türkiye; https://orcid.org/0000-0002-4784-402X

3. Dokuz Eylül Üniversitesi, Buca Eğitim Fakültesi, İzmir, Türkiye; https://orcid.org/0000-0003-0610-863X

Atıf / Citation: Demircan, U., \& Aydın, I.S. (2019). Ortaokul öğrencilerinin dinleme/izleme öz-yeterliklerinin çeşitli değişkenlere göre incelenmesi.Kastamonu Education Journal, 27(4), 1517-1527. doi:10.24106/kefdergi.3119 


\section{Extended Abstract}

Problem Status: Self-efficiency belief, one of the basic concepts of Social Learning Theory, is one of the factors that directly affect the learning of the individual. The self- efficiency perception that is studied on many areas is also an important factor in the development of listening skills, which are considered to be the most important of the four basic language skills. From this point of view, self- efficiency perception towards listening skills and determining which factors and level of influence of these factors are very important in terms of Turkish language education.

This study aims to determine listening/watching self- efficiency belief levels of 6th, 7th and 8th grade students of middle school and to evaluate the obtained results according to factors such as class level, gender, parental education status and Turkish lesson achievement score.

Method: The research is a descriptive study on "Relational Screening Model". In the context of this model, the research was carried out in a correlational research method depending on the quantitative research. The research population consists of students studying in middle school attached to the Ministry of Education in Turkey. The sample consists of 748 students in 6th, 7th and 8th grade level determined according to the method of "simple random sampling" from different schools in İzmir province.

The "Listening Self- Efficiency Scale" (Aydın et al., 2015), which has been pre-validated reliability and validity was used in the study. Confirmatory factor analysis was performed on a sample group of 240 people to obtain additional evidence of the validity and reliability of the scale. It has been verified that the scale validity is quite high according to the obtained analysis results.

Findings: As a result of the research, the listening self-efficiency mean of 6th, 7th and 8th grade students in the sample were found to be at a good level ( $\bar{X}=3.87$ ). When examined by class level; 6 th grade students had the highest listening self- efficiency, 8th grade students had the lowest listening self efficiency. According to gender, female students had more listening self- efficiency than male students. According to level of parental education, as the level of parental education increases, the self- efficiency of listening increases. It has been found that there is a positive correlation between the achievement score and listening self-efficiency according to the achievement points of Turkish lessons of the previous year.

Results and Suggestions: This study and other studies on the subject reveal the importance of self-sufficiency in education. Therefore, it is necessary to implement practices that will increase self-sufficiency in education.

It should be ensured that the parents receive the necessary education and support in raising their children, considering that the educational situation of the parents affects the listening skill of the child and the language skills.

As a result of this study, it was seen that the gender factor was effective on listening self-efficacy. It can be investigated whether this result is related to the breeding pattern or brain structure.

From the results of this study, it is seen that the child's class level and developmental period affect the self-efficacy perception of listening. When the activities related to listening skills are organized, this effect should be taken into consideration and appropriate self-efficacy enhancing activities should be included in the child's class level and development period. 


\section{Giriş}

İletişim geçmişten günümüze insan ilişkilerinde belirleyici bir unsur olmuştur. İletişim kurmanın en temel yolu dildir. Dil aynı zamanda kültürün en önemli parçasını oluşturur. Bilginin, ilmin ve kültürün aktarımını sağlayan dil uygarlığın olmazsa olmaz bir parçasıdır. Sever'e göre (2011: 5) anlamayı ve anlatmayı sağlayan dil; düşünme ve düşünceyi geliştirme aracıdır, toplumu oluşturan en önemli ögedir ve insanlığın bütün birikimini aktarmaya yarayan en etkili araçtır.

Dil becerilerinin her biri karmaşık bir yapıya sahiptir ve farklı becerilerden oluşur. Dil becerileri temelde alıcı ve verici beceriler olarak gruplanabilir. Anlama becerileri dinleme ve okuma, anlatma becerileri ise konuşma ve yazmadır. Bu temel beceriler birbiriyle etkileşim hâlinde olduğundan birinde görülen bir gelişme diğer becerileri de etkilemektedir.

Dinleme becerisi için yapılmış tanım ve açıklamalar, dinlemenin işitmeden farklı olduğu ve daha fazlasını gerektirdiği yönündedir (Demirel, 1999; Göğüş, 1978; Sever, 2000; Ungan, 2007; Özbay, 2006; Ergin ve Birol, 2000; Çifçi, 2001; Johnson, 1951; Hampleman, 1958; Wolff, Marsnik, Tacey ve Nichols, 1983; Jalongo, 1995: 13; Aktaş ve Gündüz, 2004: 19; Yüksel, 2008: 174). Dinleme öğrenilmesi gereken bir beceriyken işitmenin ise doğal bir süreç olması, dinleme seçerek ve isteyerek yapılırken işitmenin ise bireyin kontrolünde olmaması, insan her şeyi işitebilirken her şeyi dinleyememesi, dinlemenin irade gerektirmesi, dinlemenin anlamlandırma ile neticelenmesi dinlemeyi işitmeden ayıran özelliklerdir. Bazı tanımların izleme sürecini de dinlemeye dâhil ettikleri görülmektedir (Ergin ve Birol, 2000; Göğüş, 1978; Ungan, 2007). Tüm bu bilgilerden ve dinlemenin özelliklerinden hareketle dinleme, bir konuşmacının ya da konuşma kaynağının ilettiği sözel ve varsa görsel işaretleri zihinde anlamlandırma sürecidir, diye tanımlanabilir.

Dinleme araştrrmacılar tarafindan en temel dil becerisi olarak kabul görmüş ve önemsenmiştir. Dinleme becerisini önemli yapan nedenler şunlardır:

- Doğumdan önce, hatta anne karnında, kazanılan tek beceridir.

- Dil becerilerinin kazanılmasında ve gelişmesinde bir temel oluşturur.

- Diğer dil becerilerinin öğretilmesinde en çok kullanılan beceridir.

- Günlük yaşam, eğitim ve iş yaşamında en çok kullandığımız dil becerisidir (Aydın vd. 2015).

Mackay’a göre (1997: 10) "ihmal edilmiş bir beceri” diye anılan, zamanımızın çok büyük bir bölümünü harcadığımız dinleme eylemi; sahip olduğumuz en önemli becerilerimizden biri olmakla birlikte en az tanınan becerimizdir. Ozman ve Gürbüz'e göre (2006: 140) Türkçe derslerinde dinleme ile ilgili etkinlikler, diğer etkinliklere kıyasla geri planda kalmakta, bu sebeple bireylerin 'etkili dinleme' becerisi kazanmaları daha az oranda gerçekleşmektedir. Özbay ve Melanlıoğlu'na göre (2012) dil becerileri içerisinde üzerinde en az durulanı dinlemedir. Bu, dinlemenin fark edilmeden edinilen ve kullanılan bir beceri olmasından kaynaklanmaktadır. Bu sebeple dinleme hem eğitim hem de toplum hayatında "ihmal edilmiş" bir beceri olarak kalmaktadır.

Ülkemizde ve dünyada ihmal edilen dinleme becerisine eğitim öğretimde ve yaşamın diğer alanlarında gereken önem verilmelidir. Anlama becerisi yüksek olan bireylerin öğrenme ve anlama kapasiteleri doğal olarak artacağından başarılı bir toplum oluşturmak için dinleme becerisinin geliştirilmesi şarttır.

\section{Öz Yeterlik ve Dinleme Öz Yeterliği}

Alanyazında öz yeterlik kavramına yönelik yapılmış farklı tanımlar mevcuttur. Öz yeterlik, kişinin belli bir performansı göstermesi için gerekli etkinlikleri başarılı bir biçimde gerçekleştirilmesine dair kendisiyle ilgili yargısı olarak ifade edilmektedir. Albert Bandura (1994) öz yeterlik inancını bireyin belirli bir performansı göstermek amacıyla gereken eylemleri koordine etme ve başarılı olarak gerçekleştirme kapasitesi ile alakalı yargısı olarak ifade etmektedir. Snyder ve Lopez'e göre (2002: 278) öz yeterlik, gözlem ile algılanabilecek bir beceri değildir. Belli koşullarda bireyin becerileri ile "Neler yapabilirim?" sorusuna verdiği cevapla ilgili duyduğu içsel inançttr. Öz yeterlik; kapasite, özel performans hakkındaki algılarla ilgili değildir. Ancak durumlarla başa çıkmada ve bunu değiştirmede, yeteneklerini ve becerilerini düzenlemek için bireyin yapabileceklerine olan inancıdır (Varlıŏlu, 2013: 9). Öğrenme kapasiteleri ve yetenekleri konusunda şüpheleri olan kişilere göre bir beceri ya da konuyu öğrenmede yüksek öz yeterlik algısına sahip bireyler daha iyi uyum gösterir, daha sıkı çalışır, zorluklarla karşılaştıklarında çok daha dayanıkı olur ve pes etmezler (Zimmerman, 2000; Pajares 2002).

Bandura'ya göre (2004: 622) öz yeterlik üzerinde etkili olan dört unsur vardır. Bu unsurlar şu şekilde özetlenebilir:

Doğrudan deneyimler: Bireylerin öz yeterliği üzerinde en etkili olan faktör, birebir yaşadıkları olayları ifade eden doğrudan deneyimlerdir. Bireylerin, gösterdikleri davranışların sonuçlarını ölçmesi ve değerlendirmesi yeterlilik inançlarını belirlemektedir. Değerlendirmeler sonucunda birey başarılı olduğunu düşünüyorsa öz yeterlik olumlu, kendini 
başarısız olarak değerlendiriyorsa öz yeterlik olumsuz etkilenir.

Dolaylı deneyimler: Bireylerin çevrelerindeki kişilerin başarılarına tanıklık etmeleri, kendilerinin de başarılı olacağı inancını oluşturur. Akranlarının kararlılık ve performanslarını kendilerine örnek alan bireyler, öğrenme yoluyla aynı davranış ve tutumları uygulamaya çalışır. Ayrıca örgüt ortamındaki ödüllendirme sistemleri de diğer çalışanları motive etmek ve başarılı olma inancını artırmak için uygulanmaktadır.

İkna Etme: Bireylerin yeterliklerini güçlendiren üçüncü unsur ikna etmedir. Bireyi başarıya ulaşmak için gerekli olan özelliklere sahip olduğuna inandırmak öz yeterliği artırır. Böylece bireyde problem durumlarında eksiklikler üzerinde durarak daha fazla çaba gösterme isteği uyanır.

Fiziksel ve Duygusal Durum: Bireyler kendi yetenekleri hakkında karar verirken içinde bulundukları fiziksel ve duygusal durumdan etkilenirler. Gerginlik, kaygı ve depresyon gibi duygusal durumlar kişisel yetersizliklerin işareti olarak görülmektedir ve öz yeterliği olumsuz etkilemektedir. Güç ve dayanıklılık isteyen aktivitelerde bireyler yorgunluk ve acıyı fiziksel zayıflı̆ın birer göstergesi olarak nitelendirmektedir ve bu durum öz yeterliğe olumsuz etki etmektedir. Duygusal ve fiziksel olarak iyi durumda olan kişinin ise öz yeterlik algısı olumlu etkilenmektedir.

Dinleme öz yeterliği kişinin kendi dinleme becerisi ile ilgili etkili dinleme, dinlediğini anlama, dinleme stratejilerine hâkim olma ve bu stratejileri uygulayabilme konularında sahip olduğu yeterlik algısıdır. Öz yeterlik inancı hem performansı etkiler hem de performanstan etkilenir. Bu nedenle dinleme öz yeterliğinin kişinin akademik yaşamında çok önemli bir yeri olduğu söylenebilir. Birey dinleme davranışına, sahip olduğu dinleme öz yeterlik algısı kadar devam edecektir ve aynı zamanda dinleme öz yeterlik algısı dinleme performansını etkileyecektir. Bireyin hem dinleme alışkanlığını sürdürmesi hem de etkin bir şekilde dinlemesi, sahip olduğu dinleme öz yeterliğiyle yakından ilişkilidir. Bu çalışmada ortaokul öğrencilerinin dinleme/izleme öz yeterlik düzeyleri ölçülmüş; elde edilen sonuçlar sınıf düzeyi, cinsiyet, anne-baba eğitim durumu, önceki yıl Türkçe dersi başarı puanı gibi değişkenlere göre incelenmiştir. Buna bağlı olarak çalışmanın problem cümlesi “Ortaokul öğrencilerinin dinleme/izleme öz yeterlik algıları ne düzeydedir?” olarak belirlenmiştir. Çalışmanın alt problem cümleleri ise şunlardır:

1. Ortaokul öğrencilerinin dinleme/izleme öz yeterlik algıları sınıf düzeyine göre anlamlı bir farklılık göstermekte midir?

2. Ortaokul öğrencilerinin dinleme/izleme öz yeterlik algıları cinsiyete göre anlamlı bir farklılık göstermekte midir?

3. Ortaokul öğrencilerinin dinleme/izleme öz yeterlik algıları anne-baba eğitim durumuna göre anlamlı bir farklılık göstermekte midir?

4. Ortaokul öğrencilerinin dinleme/izleme öz yeterlik algıları ile önceki yıla ait Türkçe dersi başarı puanı arasında anlamlı bir ilişki var mıdır?

\section{Yöntem}

Bu bölümde araştırmanın deseni, çalışma grubu,veri toplama araçları ve süreci ile verilerin analizine yer verilmiştir.

\section{Araştırmanın Deseni}

Bu çalışma “ilişkisel Tarama Modeli”nde betimsel bir çalışmadır. Illişkisel model iki ya da daha fazla değişken arasında birlikte değişimin varlığını veya değişimin derecesini belirlemeyi amaçlayan araştırma modelidir (Büyüköztürk ve diğer., 2015: 23). Bu model bağlamında araştırma, nicel araştırmaya bağlı olarak korelasyonel araştırma yönteminde gerçekleştirilmiştir.

\section{Evren ve Örneklem}

Araştırmanın evrenini İzmir ilinde MEB'e bağıı ortaokullarda eğitim gören öğrenciler oluşturmaktadır. Araştırmanın örneklemi ise İzmir ili Bayraklı, Buca ve Bornova ilçelerindeki çeşitli okullardan "basit seçkisiz örneklem" yöntemine göre belirlenmiş 6, 7 ve 8. sınıf düzeyindeki 748 öğrenciden (369 kız, 379 erkek) oluşmaktadır. Bu çalışmada kullanılan "Dinleme Öz Yeterlik Ölçeği" 6,7 ve 8. sınıflara yönelik hazırlandığından beşinci sınıflar araştırmaya dâhil edilmemiştir. Ayrıca bu çalışmanın veri toplama süreci, ilköğretim okullarının, ilkokul ve ortaokula dönüşüm evresinde gerçekleştirilmesinden dolayı beşinci sınıflar kapsam dışı tutulmuştur.

Örneklemi oluşturan katılımcıların sınıf düzeylerine göre dağııımı ise Tablo 1'de gösterilmiştir: 
Tablo 1. Katılımcıların Sınıf Düzeyine Göre Dağılımı

\begin{tabular}{lcc}
\hline Sınıf Düzeyi & $\mathrm{n}$ & $\%$ \\
\hline 6. Sınıf & 284 & 38 \\
7. Sınıf & 304 & 40,6 \\
8. Sınıf & 160 & 21,4 \\
Toplam & 748 & 100 \\
\hline
\end{tabular}

Tablo 1'de görüldüğü üzere katlımcıların \%38'ini $(f=284)$ 6. sınıf düzeyindeki öğrenciler, \%40,6'sını $(f=304) 7$. sınıf düzeyindeki öğrenciler, \%21,4'ünü $(f=160)$ ise 8 . sınıf düzeyindeki öğrenciler oluşturmaktadır.

Tablo 2. Kathlımcıların Anne-Baba Eğitim Düzeylerine Göre Dağılımı

\begin{tabular}{lcc}
\hline Anne Ĕgitim Durumu & $\mathrm{n}$ & $\%$ \\
\hline Okuryazar Değil & 82 & 10,9 \\
İlkokul & 271 & 36,0 \\
Ortaokul & 240 & 31,9 \\
Lise & 132 & 17,6 \\
Üniversite & 23 & 3,6 \\
Toplam & 748 & 100 \\
\hline Baba Eğitim Durumu & $\mathrm{n}$ & $\%$ \\
\hline Okuryazar Değil & 18 & 2,4 \\
İlkokul & 208 & 27,9 \\
Ortaokul & 255 & 34,1 \\
Lise & 213 & 28,5 \\
Üniversite & 53 & 7,1 \\
Toplam & 747 & 100
\end{tabular}

Tablo 2'ye göre katılımcıların anne eğitim düzeyleri şu şekildedir: Okuryazar olmayan $\% 10,9$ ( $f=82)$, ilkokul mezunu \%36 $(f=271)$, ortaokul mezunu \%31,9 $(f=240)$, lise mezunu \%17,6 $(f=132)$, üniversite mezunu \%3,6 $(f=23)$.

Tablo 2'ye göre baba eğitim düzeyleri ise şu şekildedir:

Okuryazar olmayan $\% 2,4(f=18)$, ilkokul mezunu $\% 27,9(f=208)$, ortaokul mezunu $\% 34,1(f=255)$, lise mezunu $\% 28,5$ $(f=213)$, üniversite mezunu $\% 7,1(f=53)$.

Tablo 3. Katılımcıların Önceki Yıl Türkçe Dersi Başarı Puanları

\begin{tabular}{lll}
\hline Önceki Yıl Türkçe Başarı Puanı & $\mathrm{n}$ & $\%$ \\
\hline $0-44$ & 22 & 2,9 \\
$45-54$ & 64 & 8,6 \\
$55-69$ & 187 & 25,0 \\
$70-84$ & 256 & 34,2 \\
$85-100$ & 219 & 29,3 \\
Toplam & 748 & 100 \\
\hline
\end{tabular}

Tablo 3'e göre katılımcıların \%2,9'unun ( $f=22$ ) önceki yıla ait Türkçe dersi başarı puanlarının 0-44 (zayıf), \%8,6'sının $(f=64)$ 45-54 (geçer), \%25'inin ( $f=187$ ) 55-69(orta), \%34,2'sinin $(f=256)$ 70-84(iyi), \%29,3'ünün ( $f=219$ ) 85-100 (pekiyi) düzeyinde olduğu saptanmıştir.

\section{Veri Toplama Araçları ve Süreci}

Bu çalışmada öğrencilerin dinleme öz yeterlik algılarını belirlemek için Aydın, İnnalı ve Demircan (2015) tarafindan geliştirilen; geçerliği ve güvenirliği önceden saptanmış "Dinleme Öz Yeterlik Ölçeği (DÖYÖ)" kullanılmıştr. Aydın, İnnalı ve Demircan’a göre (2015: 1432) geçerliği ve güvenirliği oldukça yüksek olan bu ölçekten elde edilecek yüksek puan, öğrencilerin yüksek öz yeterliğe, düşük puan ise düşük öz yeterliğe sahip olduklarının göstergesi olarak değerlendirilebilir.

"Dinleme Öz Yeterlik Ölçeği (DÖYÖ)" araştırmacılar tarafindan geliştirilirken 541 katılımcıdan oluşan bir çalışma grubu üzerinde uygulanmıştır. Verilerin analizinde açımlayıcı faktör analizi kullanılmıştır. Verilerin faktör analizine uygunluğu Kaiser-Meyer-Olkin (KMO) katsayısı ve Bartlett Küresellik Testi ile kontrol edilmiştir. "Dinleme Öz Yeterlik Ölçeği”nin 
(DÖYÖ) yapı geçerliğini ve faktör yapısını incelemek için temel bileşenler analizi yapılmıştr. Analizlerde faktörlerin her değişken üzerindeki ortak faktör varyansı maddelerin faktör yükleri, açıklanan varyans oranları ve yamaç birikinti grafiği incelenmiştir. Güvenirlik analizinde madde-toplam korelasyonu Cronbach alfa iç tutarlık katsayısı hesaplamasına bağı olarak elde edilen analiz sonucunda ölçeğin bütününe ait iç tutarlık katsayısı 0,97 olarak bulunmuştur. Elde edilen bu değer ölçme aracının güvenirliğinin yüksek düzeyde olduğunu göstermektedir. Araşttrma sonucunda toplam 56 maddeden oluşan tek faktörlü ve güvenirliği oldukça yüksek "Dinleme Öz Yeterlik Ölçeği (DÖYÖ)" olarak geliştirilen ölçeğin, ortaokul öğrencilerinin dinleme öz yeterliklerini ölçmek için kullanılabilecek geçerli ve güvenilir bir araç olduğu saptanmıştır.

Açımlayııı faktör analizi sonuçlarına ek kanıt elde etmek için doğrulayıcı faktör analizi yapıımıştır. Analiz için 240 kişilik katılımcı grubuna ölçek uygulanmış, elde edilen veriler Açımlayıcı Faktör Analizi sonuçlarına uygun şekilde tek boyutlu olarak doğrulayıcı faktör analizi yapılmıştır.

Gizil değişkenlerin gözlenen değişkenleri açıklama düzeyi hakkında bilgi veren t-değerlerinin (Chi-Square=2780.35, $\mathrm{df}=1485$, P-value=0.0, RMSEA=0.060) bütün maddeler için 0.01 düzeyinde anlamlı olduğu görülmektedir. Ölçekteki maddelere ilişkin faktör yüklerinin (standardize edilmemiş tahmin değerleri) $0.44-0.74$ arasında değerler aldığı görülmektedir. Analiz sonucunda elde edilen her bir gözlenen değişken ile bağlı olduğu gizil değişken arasındaki korelasyonları gösteren standardize edilmiş faktör yük değerleri ise 0.46-0.70 arasında değişmektedir. Gizil değişkene ilişkin varyansın ne kadarının gözlenen değişken tarafindan açıklandığını ifade eden $\mathrm{R}^{2}$ değerleri ise $0.21-0.50$ arasında değişmektedir. Gözlenen değişkenlerin hata varyans değerinin yüksek olduğu madde bulunmamaktadır.

Beklenen ile gözlenen kovaryans matrisi arasındaki farkın anlamlılığını gösteren p değeri 0.0 düzeyinde anlamlı bulunmuştur. Yılmaz ve Çelik'e göre (2009) örneklemin büyük olduğu durumlarda $p$ değerinin manidar çıkma ihtimali yüksektir. Bundan dolayı beklenen ve gözlenen kovaryans matrisleri arasındaki farkın incelenmesi için alternatif uyum değerlerine bakılmıştr:

Tablo 4. Ölçeğin Uyum İndeksi Değerleri

\begin{tabular}{ccccccc}
\hline X2/df & RMSEA & SRMR & GFI & IFI & NNFI & CFI \\
\hline 1,874 & 0,060 & 0,053 & 0,71 & 0,98 & 0,97 & 0,98 \\
\hline Mükemmel & Mükemmel & İyi uyum & Uygun değil & Mükemmel & Mükemmel & Mükemmel \\
\hline
\end{tabular}

Tablo 4'e göre X²/df oranı (2780.35/1484) 1.874 olarak hesaplanmışttr. Bu değerin 3'ün altında olması mükemmel uyum derecesini göstermektedir. Hesaplanan RMSEA değeri 0.060 'ın 0.05 'ten küçük olması mükemmel uyum ölçütüne karşılık gelmektedir (Sümer, 2000). Standardize edilmiş RMR değeri 0.053 'tür ve değerin 0.05 'ten küçük olması mükemmel uyuma karşılık gelmektedir (Brown, 2006; akt: Çokluk, Şekercioğlu ve Büyüköztürk, 2010). GFI değerinin 0.71 olduğu ve uygun olmadığı görülmektedir. GFI değeri için 0.85 'ten daha büyük değerler kabul edilebilir uyumun göstergesidir (Yılmaz ve Çelik, 2009). IFI, NNFI ve CFI indekslerin 0.95 'in üzerinde olması mükemmel uyum anlamına gelir (Tabachnick ve Fidell, 2001 akt: Aydın ve diğer., 2017). Tabloda bu uyumların sırasıyla 0.98, 0.97, 0.98 olduğu görülmekte ve tüm değerler mükemmel uyuma karşılık gelmektedir.

Madde modifikasyon önerileri incelendiğinde uyum değerlerinin artması için 22. ve 23. maddelerin birleştirilmesinin önerildiği görülmüştür. Maddelerin "Dinlediklerimde geçen sebep-sonuç ilişkilerini fark etmede" ve "Dinlediklerimde geçen amaç-sonuç ilişkilerini fark etmede" şeklindeki maddeler olduğu görülmüştür. Yakın olmasına rağmen bunarın farklı kazanımları ölçen maddeler olduğu, kişide biri yüksek olduğu hâlde diğerinin düşük olabileceği göz önünde bulundurularak ve alanyazına uygun olmadığı için maddelerin birleştirilmesi yoluna gidilmemiştir.

\section{Verilerin Analizi}

Verilerin analizinde SPSS 17.0 paket programı kullanılmıştır. Verilerin analizinde tek değişkenli istatistiklerde kullanılan Tukey testi, bağımsız t-testi, bağımlı iki örnek t-testi kullanıımıştır. Kullanılan testler ilgili bulgularda sunulmuştur.

\section{Bulgular}

Çalışmaya yönelik elde edilen bulgular şu şekildedir: 
Tablo 5. Ortaokul Öğrencilerinin Dinleme Öz-Yeterlik Düzeyleri

\begin{tabular}{ccccc}
\hline $\mathrm{n}$ & En Küçük Değer & En Büyük Değer & $\bar{X}$ & Standart Sapma \\
\hline 748 & 1,07 & 5,00 & 3,8665 &, 60716 \\
\hline
\end{tabular}

Tablo 5 'te görüldüğü üzere örneklemde yer alan 748 ortaokul öğrencisinin dinleme öz yeterlik algılarının aritmetik ortalamasının iyi ( $\bar{X}=3.87)$ düzeyde olduğu saptanmıştr.

Tablo 6. Sınıf Düzeyine Göre Öğrencilerin Dinleme Öz-Yeterlik Düzeyleri

\begin{tabular}{ccccc}
\hline Sınıf Düzeyi & $\mathrm{n}$ & $\overline{\mathrm{X}}$ & Standart Sapma & Standart Hata \\
\hline 6. Sınıf & 284 & 3,9949 &, 59627 &, 03538 \\
7. Sınıf & 304 & 3,8060 &, 64081 &, 03675 \\
8. Sınıf & 160 & 3,7537 &, 51705 &, 04088 \\
\hline
\end{tabular}

Tablo 6'da yer alan Tukey testi sonuçlarına bakıldığında 6. sınıfta okuyan öğrencilerin dinleme öz yeterlik algılarının aritmetik ortalaması $\bar{X}=3.99$, 7. sınıfta okuyan öğrencilerin dinleme öz yeterlik algılarının aritmetik ortalaması $\bar{X}=3.80,8$. sınıfta okuyan öğrencilerin dinleme öz yeterlik algılarının aritmetik ortalamasının ise $\bar{X}=3.75$ olduğu görülmektedir. Bu değerlere göre dinleme öz yeterlik algıları sınıf düzeylerine göre şöyle sıralanabilir: 6 . Sınıf $>7$. Sınıf $>8$. Sınıf.

Tukey testi sonuçlarına göre ortaokul 6, 7 ve 8. sınıf öğrencileri arasında dinleme öz yeterlik düzeyi bakımından 6 . sınıf öğrencileri ile 7. sınıf ve 8 . sınıf öğrencileri arasında $(6-7,6-8) p<0.05$ olduğundan anlamlı bir farklılık olduğu sonucuna ulaşılmıştır.

Tablo 7. Cinsiyete Göre Öğrencilerin Dinleme Öz-Yeterlik Düzeyleri

\begin{tabular}{lcccc}
\hline Cinsiyet & $\mathrm{n}$ & $\overline{\mathrm{X}}$ & Standart Sapma & Standart Hata \\
\hline Kız & 369 & 3,9946 &, 57532 &, 02995 \\
Erkek & 379 & 3,7418 &, 61210 &, 03144 \\
\hline
\end{tabular}

Tablo 7'de yer alan bağımsız t testi sonucuna göre örneklemi oluşturan 369 kız öğrencinin dinleme/izleme öz yeterlik algılarının aritmetik ortalaması $\bar{X}=3.99$, örneklemi oluşturan 379 erkek öğrencinin dinleme/izleme öz yeterlik algılarının aritmetik ortalamasından $\bar{X}=3.74$ daha büyüktür. Hem kız hem de erkek öğrencilerin öz yeterlik düzeylerinin "İyi" düzeyde olduğu saptanmıştır. Ayrıca $p<0.05$ olduğundan cinsiyetler arasında kız öğrenciler lehine gözlenen farkın anlamlı olduğu sonucuna ulaşılmıştır.

Tablo 8. Anne Eğitim Durumuna Göre Öğrencilerin Dinleme Öz-Yeterlik Düzeyleri

\begin{tabular}{lcccc}
\hline Anne Eğitim Durumu & $\mathrm{n}$ & $\overline{\mathrm{X}}$ & Standart Sapma & Standart Hata \\
\hline Okuryazar Değil & 82 & 3,7557 &, 55032 &, 06077 \\
ilkokul & 271 & 3,8362 &, 61200 &, 03718 \\
Ortaokul & 240 & 3,8611 &, 58361 &, 03767 \\
Lise & 132 & 3,9468 &, 65167 &, 05672 \\
Üniversite & 23 & 4,2143 &, 59509 &, 12408 \\
\hline
\end{tabular}

Tablo 8'e göre örneklemi oluşturan katlımcılardan annesi okuryazar olmayan 82 öğrencinin dinleme öz yeterlikleri aritmetik ortalamalarını $\bar{X}=3.76$, annesi ilkokul mezunu olan 271 öğrencinin dinleme öz yeterlikleri aritmetik ortalamalarının $\bar{X}=3.84$, annesi ortaokul mezunu olan 240 öğrencinin dinleme öz yeterlikleri aritmetik ortalamalarının $\bar{X}=3.86$, annesi lise mezunu olan 132 öğrencinin dinleme öz yeterlikleri aritmetik ortalamalarının $\bar{X}=3.95$, annesi üniversite mezunu olan 23 öğrencinin dinleme öz yeterlikleri aritmetik ortalamalarının $\bar{X}=4.21$ olduğu görülmektedir. Elde edilen bu veriye göre ortaokul öğrencilerinin anne eğitim durumuna göre dinleme öz yeterlikleri aritmetik ortalamaları şu şekilde sıralanabilir: Üniversite >Lise >Ortaokul >ilkokul >Okuryazar değil.

Tukey testi sonuçlarına göre anne eğitim düzeyi üniversite olan katılımcılar ile anne eğitim düzeyi okuryazar olmayan ve ilkokul olan katılımcılar arasında (Ü-OYD, Ü-i) $p<0.05$ olduğundan dinleme öz yeterliği bakımından anlamlı fark vardır. 
Tablo 9. Baba Eğitim Durumuna Göre Öğrencilerin Dinleme Öz-Yeterlik Düzeyleri

\begin{tabular}{lcccc}
\hline Baba Eğitim Durumu & $\mathrm{n}$ & $\overline{\mathrm{X}}$ & Standart Sapma & Standart Hata \\
\hline Okuryazar Değil & 18 & 3,5952 &, 53851 &, 12693 \\
Illkokul & 208 & 3,8551 &, 60667 &, 04207 \\
Ortaokul & 255 & 3,8022 &, 60368 &, 03780 \\
Lise & 213 & 3,9248 &, 60787 &, 04165 \\
Üniversite & 53 & 4,0822 &, 58400 &, 08022 \\
\hline
\end{tabular}

Tablo 9'a göre örneklemi oluşturan babası okuryazar olmayan 18 öğrencinin dinleme öz yeterliklerinin aritmetik ortalamalarının $\bar{X}=3.60$, babası ilkokul mezunu olan 208 öğrencinin dinleme öz yeterliklerinin aritmetik ortalamalarının $\bar{X}=3.86$, babası ortaokul mezunu olan 255 öğrencinin dinleme öz yeterliklerinin aritmetik ortalamalarının $\bar{X}=3.80$, babası lise mezunu olan 213 öğrencinin dinleme öz yeterliklerinin aritmetik ortalamalarının $\bar{X}=3.92$, babası üniversite mezunu olan 53 öğrencinin dinleme öz yeterliklerinin aritmetik ortalamalarının $\bar{X}=4.08$ olduğu görülmektedir. Elde edilen bu verilere göre ortaokul öğrencilerinin dinleme öz yeterlikleri baba eğitim durumuna göre şu şekilde sıralanabilir: Üniversite> Lise>lilkokul>Ortaokul>Okuryazar değil.

Tukey testi sonuçlarına göre baba eğitim düzeyi üniversite olan katlımcılar ile baba eğitim düzeyi okuryazar değil ve ortaokul olan katılımcılar arasında (Ü-OYD, Ü-O) p<0.05 olduğundan dinleme öz yeterlik düzeyi bakımından anlamlı fark vardır.

\section{Tablo 10. Önceki Yıl Türkçe Dersi Başarı Puanına Göre Öğrencilerin Dinleme Öz-Yeterlik Düzeyleri}

\begin{tabular}{lcccc}
\hline Türkçe Başarı Puanı & $\mathrm{n}$ & $\overline{\mathrm{X}}$ & Standart Sapma & Standart Hata \\
\hline $0-44$ & 22 & 3,2313 & 3,2313 &, 66074 \\
$45-54$ & 64 & 3,3742 & 3,3742 &, 68221 \\
$55-69$ & 187 & 3,5974 & 3,5974 &, 50422 \\
$70-84$ & 256 & 3,8690 & 3,8690 &, 50273 \\
$85-100$ & 219 & 4,3011 & 4,3011 &, 45864 \\
\hline
\end{tabular}

Tablo 10'a göre önceki yıla ait başarı puanları 0-44 aralığında olan 22 öğrencinin dinleme öz yeterlikleri aritmetik ortalamalarının $\bar{X}=3.23$, önceki yıla ait başarı puanları 45-54 aralığında olan 64 öğrencinin dinleme öz yeterlikleri aritmetik ortalamalarının $\bar{X}=3.37$, önceki yıla ait başarı puanları 55-69 aralığında olan 187 öğrencinin dinleme öz yeterlikleri aritmetik ortalamalarının $\bar{X}=3.60$, önceki yıla ait başarı puanları 70-84 aralığında olan 256 öğrencinin dinleme öz yeterlikleri aritmetik ortalamalarının $\bar{X}=3.87$, önceki yıla ait başarı puanları 85-100 aralığında olan 219 öğrencinin dinleme öz yeterlikleri aritmetik ortalamalarının $\bar{X}=4.30$ olduğu görülmektedir. Elde edilen bu verilere göre ortaokul öğrencilerinin dinleme öz yeterlikleri önceki yıla ait Türkçe dersi başarı puanına göre şöyle sıralanabilir: (85-100) > (70-84) > (55-69) $>(45-54)>(0-44)$.

Yapılan tek örneklemli t testi sonucuna göre önceki yıl Türkçe dersi başarı puanına göre ortaokul öğrencilerinin dinleme öz yeterlikleri $p<0.05$ olduğundan anlamlı bir farklıık göstermektedir. Bu da Türkçe dersi başarı puanları ile dinleme öz yeterlik düzeyi arasında anlamlı bir ilişkinin olduğunu ortaya koymaktadır.

\section{Sonuçlar}

Çalışmanın analiz sonuçlarına göre ortaokul öğrencilerinin dinleme konusundaki öz yeterlik düzeylerinin $\bar{X}=3.87$ olduğu saptanmıştr. Öğrencilerin dinleme konusunda kendilerini "iyi” düzeyde yeterli gördüğü anlaşılmaktadır. Ürün Karahan (2016) 6. sınıf öğrencilerinin dinleme becerisine yönelik farkındalıklarını ölçtüğü çalışmada öğrencilerin farkındalıklarının iyi düzeyde olduğunu saptamıştır. Elde edilen sonuçların benzerlik taşıması dinleme öz yeterliği ve farkındalığııın çok uzak kavramlar olmamasına bağlanabilir. İnnalı (2014) tarafindan yapılan çalışmada 8. sınıf öğrencilerinin okuma öz yeterliklerinin iyi $(\bar{X}=3.8)$ düzeyde olduğu saptanmıştr. Çıkan sonucun bu çalışmayla benzerlik göstermesi dil becerilerinin birbiriyle ilişkili olduğunu göstermektedir.

Sınıf düzeyine göre öğrencilerin dinleme öz yeterliğine ait bulgular incelendiğinde 6 . sınıf öğrencilerinin dinleme öz yeterlikleri $\bar{X}=3.99$ ile en yüksek çıkmıştr. Bunu 7. sınıfta okuyan öğrenciler $\bar{X}=3.80$ ile takip ederken 8 . sınıfta okuyan öğrencilerin dinleme öz yeterliklerinin $\bar{X}=3.75$ ile en düşük olduğu görülmüștür. Bu sonuçlara göre 6 . sınıf öğrencilerinin dinleme becerileri konusunda kendilerini 7 ve 8. sınıf öğrencilerine göre daha yeterli gördüğü söylenebilir. Aradaki farkın anlamlı olup olmadığına bakıldığında 6 ve 7.sınıflar arasındaki, 6 ve 8. sınıflar arasındaki farkın anlamlı olduğu, 7 ve 
8. sınıflar arasındaki farkın istatistiksel olarak anlamlı olmadığı görülmektedir. Çelebi (2008); 6, 7 ve 8. sınıflar üzerinde yürüttüğü çalışmasının sonuçlarına bağlı olarak etkili dinleme becerilerini uygulama oranlarının en yüksek 6 . sınıflarda olduğunu belirtmiştir. Benzer şekilde bu çalışmada da dinleme öz yeterlik seviyesinin en yüksek 6 . sınıflarda olduğu belirlenmiştir. Sınıf düzeyi arttkç̧a dinleme öz yeterliğinin ve etkili dinleme becerilerini uygulama oranının azalması dikkat çekicidir. Bandura'ya göre (2004: 622); gerginlik, kaygı ve depresyon kişisel yetersizliklere işaret eder ve bu durumlar kişinin öz yeterliğini düşürür. Gelişim psikolojisi ile ilgili kuramlara bakıldığında bireyler ergenlik döneminde kimlik bunalımı ve şiddetli ruh hâli değişimleri yaşar, yaşanan bu çatışma kaygı ve strese neden olur (Hall, 1916; Freud, 1977; Lewin, 1951). Gelişim döneminde yaşanan stresin sınıf düzeyi arttkç̧a ergenlik dönemine yaklaşıldığından öz yeterliğin azalmasına neden olduğu söylenebilir. Ayrıca örneklemi oluşturan öğrencilere 8. sınıfta bir üst eğitim kurumuna geçiş için sınav uygulanmaktadır. Sınav yaklaştıkça kaygının artması buna bağı olarak öz yeterliğin azalması çalışmanın bu sonucu üzerinde etkili olduğu söylenebilir.

Cinsiyet değişkenine göre ortaokul öğrencilerinin dinleme öz yeterliklerine ait bulgulara bakıldığında kız öğrencilerin $\bar{X}=3.99$, erkek öğrencilerin ise $\bar{X}=3.74$ seviyesinde olduğu ve farkın anlamlı olduğu görülmektedir. Bu sonuca göre ortaokul öğrencilerinin dinleme öz yeterlikleri bakımından cinsiyete göre anlamlı bir farklılaşmanın olduğu, kız öğrencilerin dinleme konusunda kendilerini erkek öğrencilere göre daha yeterli gördükleri söylenebilir. Alanyazında kızların dil becerileri konusunda daha iyi düzeyde olduğu sonucunu destekleyen başka çalışmalar da mevcuttur (İnnalı, 2014; Taşgın, 2015, Dumanlı, 2014; Çelebi, 2008). Alanyazında dil kullanımının cinsiyete göre nasıl değiştiğini inceleyen işlevsel beyin görüntüleme (fMRI) yönteminin kullanıldığı çalışmalar da kızların dil becerileri konusunda daha başarııı olduğu sonucunu desteklemektedir (Horgan, 1975; Uzun, 1996; Huttenlocher vd, 1991; Herlitz vd, 1999; Gur vd, 2000; Shaywitz vd, 1995; Jaeger vd, 1998; Baxter vd, 2003). Kadın beynindeki Corpus Callosum'un erkeklerdekinden daha enli olduğu ve daha fazla sinir hücresine sahip olduğu bilinmektedir. Bu fizyolojik farklılı̆ın, dilin üretim ve anlamlandırma süreçlerinde beynin sağ yarımküresindeki işlevlerin daha etkin olmasına neden olduğu görüşü, son yıllarda artan beyin görüntüleme çalışmalarında ulaşılan bulgularla da desteklenmektedir (Ergenç, 2012). Kız öğrencilerin dil becerileri konusunda daha üstün olduğu, ancak çeşitli yöntem ve tekniklerle uygulanan eğitim sürecinde erkeklerin daha fazla gelişim gösterdiği çalışmalar da mevcuttur (Yıldırım, 2007; Kaplan, 2004).

Anne-Baba eğitim durumlarına göre dinleme öz yeterliğine ait bulgular incelendiğinde annesi üniversite mezunu olan öğrencilerin öz yeterlik seviyelerinin $\bar{X}=4.21$ ile en yüksek seviyede olduğu, bunu $\bar{X}=3.95$ ile annesi lise mezunu olan öğrencilerin izlediği görülmektedir. Ardından $\bar{X}=3.86$ öz yeterlik seviyesi ile annesi ortaokul mezunu olan öğrencilerin geldiği, bunu da $\bar{X}=3.84$ ile annesi ilkokul mezunu olan öğrencilerin izlediği ve $\bar{X}=3.76$ ile annesi okuryazar olmayan öğrencilerin en düşük öz yeterlik seviyesine sahip olduğu görülmektedir. Annenin eğitim düzeyi düştükçe çocuğun dinleme öz yeterliğinin de düştüğü görülmektedir.

Baba eğitim düzeyine göre çocuğun dinleme öz yeterlik seviyesi incelendiğinde babası üniversite mezunu olan öğrencilerin $\bar{X}=4.08$ aritmetik ortalamayla en yüksek öz yeterliğe sahip olduğu, bunu $\bar{X}=3.92$ öz yeterlik ortalaması ile babası lise mezunu olan öğrencilerin takip ettiği görülmektedir. Bunların ardından babası ilkokul mezunu olan öğrencilerin dinleme öz yeterlikleri $\bar{X}=3.86$ ile üçüncü sırada gelirken babası ortaokul mezunu olan öğrencilerin öz yeterlik ortalamalarının $\bar{X}=3.80$ seviyesinde olduğu görülmektedir. Babası okuryazar olmayan öğrencilerin ise $\bar{X}=3.60$ ortalamayla en düşük dinleme öz yeterliğine sahip olduğu görülmektedir. Genel olarak babanın eğitim düzeyi yükseldikçe dinleme öz yeterliğinin de yükseldiği görülmektedir. Alanyazın; eğitimli anne ve babaların çocuklarının daha başarılı olduğunu, anne-babası üniversite mezunu olan çocukların daha fazla başarı gösterdiğini doğrulamaktadır. Çocuk gelişimi ve eğitimi konusunda yeterli bilgi sahibi olmayan anne ve babaların bu konuda eğitim almaları gerekliliği alanyazında vurgulamıştir (Coşkun ve Önkaş, 2004; Sidekli, 2005: 70). Anne-baba eğitim durumunun çocuğun dil becerileri üzerinde etkili olduğunu belirten farklı çalışmalar da mevcuttur (İnnalı,2014; Şahin, 2011; Çelebi, 2008; Yıldırım, 2007).

Öğrencilerin bir önceki yıla ait Türkçe dersi başarı puanlarına göre dinleme öz yeterliklerine ait bulgular incelendiğinde başarı puanı 85-100 aralığında olan öğrencilerin $\bar{X}=4.30$ ortalama ile en yüksek öz yeterlik düzeyine sahip oldukları, bunu $\bar{X}=3.87$ ortalama ile başarı puanı 70-84 aralığında olan öğrencilerin izlediği görülmektedir. Önceki yıla ait başarı puanları 55-69 aralığında olan öğrencilerin $\bar{X}=3.60$ ortalama ile üçüncü sırada yer aldığı, ardından $\bar{X}=3.37$ ortalama ile başarı puanları 45-54 arasında olan öğrencilerin geldiği görülmektedir. Son sırada ise $\bar{X}=3.23$ ortalama ile başarı puanı 0-44 arasında olan öğrencilerin olduğu görülmektedir. Buna göre Türkçe dersi başarı puanları ile dinleme öz yeterlik düzeyi arasında pozitif yönde bir ilişki olduğu görülmektedir. Alanyazında Türkçe dersine ait başarı puanı ile dil becerilerinin pozitif yönde bir ilişkiye sahip olduğu sonucuna ulaşan farklı çalışmalar da mevcuttur (İnnalı, 2014; Kaplan, 2004; Taşgın, 2015). 


\section{5. Öneriler}

Bu çalışmanın sonuçlarından hareketle öğretmenlere, velilere, program geliştirme uzmanlarına ve araştırmacılara şu önerilerin getirilmesi uygundur:

- Öğrencilerin dinleme öz yeterliğini artırmak amacıyla öğrencilerin dinleme becerisine yönelik kendilerini yetersiz gördüğü yönlerle ilgili etkili dinleme çalışmalarına yer verilmelidir.

- Dinleme becerisinin önemi bu çalışmada ve dinlemeyle ilgili yapılan birçok çalışmada ortaya konmuştur. Diğer dil becerilerinin edinilmesi ve geliştirilmesi dinleme ile doğrudan ilişkilidir. Bu becerilerin edinilmesi dinleme aracılığıyla olur ve bunların geliştirilmesinde dinleme becerisi sıklıkla kullanılır. Eğitim öğretim sürecinde dinleme becerisinin önemi kavranmalı ve dil becerilerinin geliştirilmesinde dinleme temel kabul edilmelidir.

- Anne-baba eğitim durumunun çocuğun dinleme becerisine, dil becerilerine etki ettiği gözönünde bulundurularak anne-babanın çocuk yetiştirmede gerekli eğitim ve desteği alması sağlanmalıdır.

- Dinleme öz yeterliğine yönelik başka çalışmalar yapılabileceği gibi, dinlemeyle ilgili öz düzenleme, öz değerlendirme, kaygı, tutum gibi alanlarda da çalışmalar yapıımalıdır.

- Bu çalışmanın sonuçlarından hareketle çocuğun sınıf düzeyinin ve içinde bulunduğu gelişim döneminin dinleme öz yeterlik algısını etkilediği görülmektedir. Dinleme becerisiyle ilgili etkinlikler düzenlenirken bu etki göz önünde bulundurulmalı, çocuğun içinde bulunduğu sınıf düzeyi ve gelişim dönemine uygun öz yeterliği arttırıcı etkinliklere yer verilmelidir.

- Bu çalışmanın sonucunda cinsiyet faktörünün dinleme öz yeterliği üzerinde etkili olduğu görülmüştür. Bu konuyla ilgili olarak ailelerin kız ve erkek çocuklarını yetiştirme tarzlarındaki hangi faktörlerin dil becerileri üzerinde etkili olduğu araştrılabilir.

- Illkokul, ortaokul, lise, yükseköğretim eğitim programlarında ve öğretmen yetiştirme programlarında dinleme becerisine ve öz yeterlik gibi dinlemeyi etkileyen faktörlere daha fazla yer verilmelidir.

\section{Kaynakça}

Aktaş, Ş., \& Gündüz, O. (2004). Yazılı ve sözlü anlatım kompozisyon sanatı. Ankara: Akçağ Yayınları.

Aydın, I.S., Demircan, U. \& İnnalı, Ö. (2015). Ortaokul öğrencilerinin dinleme/izleme öz yeterlik algılarına yönelik ölçek geliştirme çalışması. International Journal of Languages' Education and Teaching, Özel Sayı, 1420-1435. Doi: 10.18298/ijlet.313.

Aydın, I.S., İnnalı, H. Ö., \& Uyumaz, G., (2017). Üstbilişsel yazma stratejileri farkındalık ölçeği'nin geliştirilmesi ve psikometrik özelliklerinin belirlenmesi. Turkish Studies. 12(25), 169-192.

Bandura, A. (1994). Self-efficacy. in V. S. Ramachaudran (Ed.), Encyclopedia of human behavior. New York: Academic Press, 4, 71-81.

Bandura, A. (2004). swimming against the mainstream: the early years from chilly tributary to transformative mainstream. Behaviour Research and Therapy, 42, 613-630.

Baxter, L. C., Saykin, A. J., Flashman, L. A., Johnson, S. C., Guerin, S. J., Babcock, D. R., \& Wishart, H. A. (2003). Sex differences in semantic language processing: a functional MRI study. Brain and language, 84(2), 264-272.

Büyüköztürk, Ş., Çakmak, E. K., Akgün, Ö. E., Karadeniz, Ş., \& Demirel, F. (2015). Bilimsel araştırma yöntemleri. Ankara: Pegem Yayınevi.

Coşkun, M. V. \& Önkaş, N. A. (2004). illk öğretimden orta öğretime geçişte Türkçenin önemi. Orta Öğretimde Yeniden Yapılanma Sempozyumu, 20-22. Ankara: M.E.B.

Çelebi, H. M. (2008). Ilköğretim 6, 7 ve 8. sınıf öğrencilerinin olay ve düşünce yazılarına göre dinleme becerilerinin değerlendirilmesi (Muğla örneği). Yayınlanmamış Yüksek Lisans Tezi, Muğla Üniversitesi.

Çif̧̧i, M. (2001). Dinleme eğitimi ve dinlemeyi etkileyen faktörler. Afyon Kocatepe Üniversitesi Sosyal Bilimler Fakültesi Dergisi, 2(2), 165-177.

Çokluk, Ö., Şekercioğlu, G. \& Büyüköztürk, Ş. (2010). Sosyal bilimler için çok değişkenli istatistik: SPSS ve LISREL Uygulamaları. Ankara: PegemA.

Demirel, Ö. (1999). ilköğretim okullarında Türkçe öğretimi. İstanbul: Milli Eğitim Basımevi.

Dumanlı, M. (2014). Türkçe öğretmeni adaylarının yazıı anlatım öz yeterlik inançlarııın değerlendirilmesi. Yüksek Lisans Tezi, Dokuz Eylül Üniversitesi Eğitim Bilimleri Enstitüsü, İmir.

Ergenç, I. Dil, beyin ve cinsiyet. Ankara Üniversitesi, 17 Haziran 2019 tarihinde https://acikders.ankara.edu.tr/pluginfile.php/39266/mod_ resource/content/0/7.\%2OHafta.pdf adresinden erişildi.

Ergin, A., \& Birol, C. (2000). Eğitimde iletişim. Ankara: Anı Yayınları.

Freud, S. (1977). Introductory Lectures on Psychoanalysis. WW Norton \& Company.

Göğüş, B. (1978). Orta dereceli okullarımızda türkçe ve yazın eğitimi. Ankara: Gül Yayınevi.

Gur, R. C., Alsop, D., Glahn, D., Petty, R., Swanson, C. L., Maldjian, J. A., ... \& Gur, R. E. (2000). An fMRI study of sex differences in regional activation to a verbal and a spatial task. Brain and Language, 74(2), 157-170. 
Hall, G. S. (1916). Adolescence: Its psychology and its relations to physiology, anthropology, sociology, sex, crime, religion and education, 2, New York: D Appleton and Company.

Hampleman, R. (1958). Comparison of listening and reading comprehension ability of 4th and 6th grade pupils. Elementary English, 31, 49-53.

Herlitz, A., Airaksinen, E., \& Nordström, E. (1999). Sex differences in episodic memory: the impact of verbal and visuospatial ability. Neuropsychology, 13(4), 590.

Horgan, D. M. D. (1975). Language development: a cross-methodological study (Doctoral dissertation). Neuroscience. University of Michigan, Ann Arbor.

Huttenlocher, J., Haight, W., Bryk, A., Seltzer, M., \& Lyons, T. (1991). Early vocabulary growth: Relation to language input and gender. Developmental Psychology, 27(2), 236.

İnnalı, H. Ö. (2014). İlköğretim 8. sını öğrencilerinin okur öz yeterliklerinin çeşitli değişkenlere göre incelenmesi. Yüksek Lisans Tezi, Dokuz Eylül Üniversitesi Eğitim Bilimleri Enstitüsü, İzmir.

Jalongo, M. R. (1995). Promoting active listening in the clossroom. Childhood Education, 72, 13-18.

Jaeger, J. J., Lockwood, A. H., Van Valin Jr, R. D., Kemmerer, D. L., Murphy, B. W., \& Wack, D. S. (1998). Sex differences in brain regions activated by grammatical and reading tasks. Neuroreport, 9(12), 2803-2807.

Johnson, K. O. (1951). The effect of classroom training upon listening comprehension. The Journal of Communication, 1, 57-62.

Kaplan, H. (2004). İlköğretim 6. sınıf öğrencilerinin dinleme becerileri üzerine bir araştırma. Yayımlanmamış Yüksek Lisans Tezi, Gazi Üniversitesi Eğitim Bilimleri Enstitüsü, Ankara.

Lewin, K. (1951). Field theory in social science.

Mackay, I. (1997). Dinleme becerisi. (Çeviri: Aksu Bora, Onur Cankoçak), Ankara: Illkkaynak Kültür ve Sanat Ürünleri Ltd. Şti.

Ozman, E., \& Gürbüz, B. (2006). Yapılandırmacı öğrenme kuramı ışığında dinleme becerilerinin geliştirilmesine ve değerlendirilmesine yönelik bir örnek. Eğitimde Çağdaş Yönelimler III 'Yapılandırmacılık ve Eğitimi Yansımaları Sempozyumu Bildiri Kitabı. 140-142.

Özbay, M. (2006). Türkçe özel öğretim yöntemleri II. Ankara: Öncü Kitap.

Özbay, M. \& Melanlioğlu, D. (2012). Türkçe öğretim programlarının dinleme becerisi bakımından değerlendirilmesi. Electronic Turkish Studies. 7(1), 87-97.

Pajares, F. (2002). Overview of social cognitive theory and of self-efficacy. Emory University. 18 Haziran 2019 tarihinde http://people.wku. edu/richard.miller/banduratheory.pdf adresinden erişildi.

Sever, S. (2000). Türkçe öğretimi ve tam öğrenme. Ankara: Anı Yayınları.

Sever, S., (2011). Türkçe öğretimi ve tam öğrenme (5. baskı). Ankara: Anı Yayıncılık.

Shaywitz, B. A., Shaywltz, S. E., Pugh, K. R., Constable, R. T., Skudlarski, P., Fulbright, R. K., ... \& Gore, J. C. (1995). Sex differences in the functional organization of the brain for language. Nature, 373(6515), 607-609.

Sidekli, S. (2005). Ilköğretim beşinci sınıf öğrencilerinin öğretici ve öyküleyici metinlere göre okuduğunu anlama becerilerinin sınanması. Yayımlanmamış Yüksek Lisans Tezi, Gazi Üniversitesi Eğitim Bilimleri Enstitüsü.

Snyder, C. R., \& Lopez, S. (2002). Handbook of positive psychology, Oxford University Press US.

Sümer, N. (2000). Yapısal eşitlik modelleri: Temel kavramlar ve örnek uygulamalar. Türk psikoloji yazıları, 3(6), 49-74.

Şahin, A. (2011). Illköğretim 6. sınıf öğrencilerinin dinleme becerisi farkındalıklarının sosyo-ekonomik düzeye göre incelenmesi. Çankırı Karatekin Üniversitesi Sosyal Bilimler Enstitüsü Dergisi, 2(1), 178-188.

Taşgın, F. G. (2015). Türkçe öğretmeni adaylarının dinleme, konuşma, okuma ve yazma öz yeterlikleri ile öğrenme stillerinin incelenmesi. Yüksek Lisans Tezi, Atatürk Üniversitesi Eğitim Bilimleri Enstitüsü, Erzurum.

Ungan, S. (2007). Dinleme eğitimi. A Kırkkılıç, H Akyol (Ed.), illköğretimde Türkçe Öğretimi. Ankara: Pegema Yayınları.

Uzun, L. Ş. (1996). Anlamlandırma sürecinde kimi eğilimler ve cinsiyet değişkeni. Dilbilim Araştırmaları Dergisi,7, 88-99. Ankara: Bizim Büro.

Ürün Karahan, B. (2015). Ortaokul 6. sınıf öğrencilerinin dinleme becerisi farkındalıklarının çeşitli değişkenler açısından incelenmesi. Kafkas Üniversitesi Sosyal Bilimler Enstitüsü Dergisi, Ek Sayı 1, 107-115.

Varlığlu, R. (2013). Matematik öğretmen adaylarının matematiğe ve öğretmenliğe ilişkin özyeterlilik algıları. Yüksek Lisans Tezi, Marmara Üniversitesi Eğitim Bilimleri Enstitüsü, İstanbul.

Wolff, F., Marsnik, N., Tacey, W., \& Nichols, R. (1983). Perspective listening. Harcourt: Harcourt College Publishing.

Yıldııı, H. (2007). İlköğretim 3. sınıf öğrencilerinin dinleme becerileri üzerine bir araştırma. Yüksek Lisans Tezi, Abant İzzet Baysal Üniversitesi Sosyal Bilimler Enstitüsü, Bolu.

Yılmaz, V., \& Çelik, H. E. (2009). LISREL ile yapısal eşitlik modellemesi-1. Ankara: PegemA.

Yüksel, H. (2008). Etkili iletişim. Ankara: Pegem Yayınları.

Zimmerman, B.J. (2000). Attainment of self-regulation: A social cognitive perspective. In M. Boekaerts, P.R. Pintrich, \& M. Zeidner (Eds.), Handbook Of Self-Regulation. 13-39. San Diego CA: Academic Press. 